\title{
WINE CONSUMER PROFILES FROM PRODUCING AND IMPORTING COUNTRIES IN EUROPE ARE DIFFERENT
}

\section{PERFIS DO CONSUMIDOR DE VINHO DOS PAÍSES PRODUTORES E IMPORTADORES NA EUROPA SÃO DIFERENTES}

\author{
Emiliano C. Villanueva $^{1 *}$, J. Sebastián Castillo-Valero ${ }^{2}$, M. Carmen García-Cortijo ${ }^{2}$ \\ ${ }^{1}$ Department of Business Administration, Eastern Connecticut State University, 83 Windham Street, Willimantic, 06226, Connecticut, USA. \\ ${ }^{2}$ Regional Development Institute, University of Castilla-La Mancha, Campus Universitario s/n, Albacete 02071 Castilla-La Mancha, Spain. \\ *corresponding author: Tel: +1-860-465-0478, e-mail: villanuevae@easternct.edu
}

(Received 30.08.2017. Accepted 06.11.2017)

\section{SUMMARY}

This article defines the demographic and socio-economic profile of wine consumers in Europe over the past twenty-five years. It is showed that, although there could be a convergence in wine consumption in Europe, the consumer profiles of the main European wine consumer countries still differ. The article concludes that net importers wine consuming countries in Europe, in this case Germany and the United Kingdom, have wine consumers that are demographically different to the traditional European wine consumer's profile from the producing wine countries, in this case France, Italy, and Spain.

\section{RESUMO}

Este artigo define o perfil demográfico e socioeconómico dos consumidores de vinho na Europa nos últimos vinte e cinco anos. Mostra-se que, embora possa existir uma convergência no consumo de vinho na Europa, os perfis do consumidor de vinho dos principais países consumidores de vinho europeus ainda diferem. O artigo conclui que os importadores líquidos dos países consumidores de vinho na Europa, neste caso, Alemanha e Reino Unido, têm consumidores de vinhos que são demograficamente diferentes do perfil tradicional do consumidor vitivinícola europeu dos países produtores de vinho, neste caso França, Itália e Espanha.

Key words: wine, profile, demographics, consumption, Europe. Palavras-chave: vinho, perfil, demografia, consumo, Europa.

\section{INTRODUCTION}

This article defines the demographic and socioeconomic profile of wine consumers over the past twenty-five years in five European countries, three traditional producing countries (France, Italy, and Spain) and two net importers (Germany, and United Kingdom). The exponential fall in the per capita consumption of wine in the producing countries and the positive increments in the per capita consumption of wine in the net importing countries (Dal Bianco et al., 2013) show a particular topic of research interest, where determining their profiles, and how close they are, is of relevant importance.

The study of the aggregate consumption of wine is one of the great questions that have arisen with interest and concern in the most recent decades in the scientific, as well as political, economic and social arenas related to this very European product. Knowing the conditions that have affected wine consumption of each typology of countries and their consumer's profile are fundamental to advance in the knowledge of this unique past experience, as well as

\section{5}

This is an Open Access article distributed under the terms of the Creative Commons Attribution License (http://creativecommons.org/licenses/by/4.0), which permits unrestricted use, distribution, and reproduction in any medium, provided the original work is properly cited. 
to know the future prospects that are opened on the subject and in this sector so important for the agrifood and distribution industries.

The objective of this research is to analyze how the European wine demand is impacted by the variables that define, on one hand, the environment of wine consumption and, on the other hand, the characteristics of the wine consumer. The dynamics followed by two large groups of European wine consumers, three traditional producing countries (France, Italy, and Spain) and two net importers (Germany, and United Kingdom), are compared.

Similar to what Villanueva et al. (2015) studied for the American wine consumer of the last decades of the $20^{\text {th }}$ century and the beginning of this $21^{\text {st }}$ century, this article presents a historical, empirical, and econometric description of European wine consumer's demographic and socioeconomic characteristics within the years 1990 and 2014. Data analyzed and correlated correspond to official European Census variables (age, gender, household income, and level of education), and European wine industry variables (wine consumption in volume and per capita, and production). In this article, wine has been treated as a homogeneous good, while acknowledging that there are several wine categories; the data set on "wine consumption in volume" by Euromonitor (2015) does not discriminate by type of wine, it only accounts the total liters of wine consumed during a year.

The article is structured as follows. Section two presents the materials and methods, with sub-sections dedicated to the literature review and the model specification, in which the empirical model, the database, and the methodology are explained. Section three provides and discusses the econometric results. Finally, the conclusion, and the references are presented.

\section{MATERIAL AND METHODS}

\section{Literature review}

Wine consumption data is constantly observed and collected by international organizations such as the O.I.V. (International Organization of Vine and Wine), the F.A.O. (Food and Agriculture Organization), and the W.H.O. (World Health Organization). Most academic literature based on wine consumer behavior concentrates in empirical studies that examine European, American, and international wine consumers' behavior and its characteristics. This vast literature deals with consumers' responses to price changes (Antoniolli et al., 2011; Estrella Orrego et al., 2012, Caracciolo et al., 2013, to name a few); the influence of specific geographical traits and other qualitative wine characteristics on consumer preference (Lockshin et al., 2006; Gallet, 2007; Casini et al., 2009a; Mora and Moscarola, 2010; Tempesta et al., 2010; Bernabéu et al., 2012, to name a few); ways in which differences between products are communicated to the public (Boatto et al., 2011; Sam and Thompson, 2012; Sirieix et al., 2013, to name a few); the effects of state laws and taxes on the consumption of wine (Folwell et al., 1991; Smith and Mitry, 2006, to name a few), and the launch of promotional campaigns to boost wine consumption in emerging wine consuming countries (Duarte Alonso, 2012; Pappalardo et al., 2013; Barisan et al., 2015, to name a few).

Also, some authors (Smith and Mitry, 2007; Mitry and Smith, 2009; Anderson, 2010) believe that the globalization process is leading to a convergence in wine consumption patterns by structuring similar models of consumption. This hypothesis of world convergence in wine consumption was tested and corroborated by Aizenman and Brooks (2005) from a tasting perspective, and Dal Bianco et al. (2013) in quantitative and culturally terms. Some studies have empirically investigated the convergence of wine consumption in a certain geographical area and its historical evolution (i.e. Smith and Skalnik, 1995 for the E.U and the U.S.; Smith et al., 1999 and Smith and Mitry, 2007 for the E.U.; Dal Bianco et al. 2013 for the world).

The wine consumption literature shows that France, Italy and Spain are mature countries in terms of wine consumption, with a vast presence of wine in everyday life. The literature also agrees that Germany and the United Kingdom are growing in their wine consumption levels, and have not reach maturity. The literature shows a convergent process has happened within wine consumption in Europe (Smith and Skalnik, 1995; Bentzen et al., 1998; Smith et al., 1999; Bentzen et al., 2001; Smith and Mitry, 2007; Smith and Mitry, 2012).

Still, while the majority of the literature emphasizes wine consumer behavior, the topic of wine consumer demographics presents itself as a distinctive and original area of research. There have been only a few rigorous academic studies of wine consumers and the determination, in some extent, of their demographic and socioeconomic profile. Some research has been done referred to wine consumer profiles in the United Kingdom (Ritchie, 2007; Phillips and Wilson, 2016), in Spain (Gil and Sánchez, 1997; De-Magistris et al., 
2014), in Italy (Casini et al., 2009b), in France (Summerfield, 2013), in Germany (Szolnoki and Hoffmann, 2014; Wiedmann et al., 2014), in Australia and New Zealand (Bruwer et al., 2002; Johnson and Bruwer, 2003; Thomas and Pickering; 2003; Bruwer and Li, 2007), in Argentina (Yvon, 2007), in South Africa (Ndanga et al., 2009), in China (Camillo, 2012), in Chile (Palma et al., 2014), and in the U.S. (Hussain et al., 2006; Villanueva et al., 2015). These papers employ different techniques to understand domestic consumer demographics and provide a description of wine consumer profiles, mainly using psychographic variables and qualitative analysis, and in very few cases, quantitative analysis.

This article contributes to the field of wine consumer demographics by defining a demographic and socioeconomic profile of wine consumers in Europe from 1990 and until 2014 through a quantitative, econometric analysis, the first study of its kind to our knowledge. Developing a profile of the wine consumer of Europe by analyzing socioeconomic and demographic data is a viable intent of identifying which consumers are more likely to buy wine. This article is one of the initial efforts to quantify the demographic profile of wine consumers in Europe by using European Census data and, this is, therefore, its major contribution to the analysis of wine consumption in Europe.

This article defines and compares the demographic and socio-economic profile of wine consumers over the past twenty-five years in five European countries, three traditional producing countries (France, Italy, and Spain) and two net importers (Germany, and United Kingdom).

\section{Model specification}

For this empirical study, a panel of variables referring to the consumption of wine from five European countries, France, Italy, Spain, the United Kingdom and Germany has been designed. These countries, traditionally consumers, account for $78 \%$ of the E.U. consumption of wine and $39 \%$ of the world consumption of wine (OIV, 2015). The period 19902014 is studied, forming a balanced panel where the variables specified are listed in Table I.

The Environment Variables selected, WPX (Wine Price), PROD (Wine Production) and CAP (Agricultural State Policies), influence wine consumers. The variable Wine Price is used in the studies of Lockshin et al. (2006), Gallet (2007),
Camillo (2012), and Salvador (2016), among others, to conclude that prices are a significantly impactful variable on wine consumption. The variable Wine Production is introduced because, as Briz i Godino (2002) points out, "we cannot understand any production without consumption and vice versa, if the aim is to recognize the economic dynamics”. Finally, the variable Agricultural State Policies is important and representative of the wine consumption environment since the wine sector has historically been regulated in Europe (Castillo et al., 2014). In this sense, authors like Castillo and Rodriguez (2009) mention the influence that Agriculture State Policies have into the consumption of wine.

The Consumer Variables, intrinsic to the individual, are income level, age, sex, level of education, marital status, and beer consumption. These variables identify and describe the consumer profile and its evolution. Authors such as Bardaji (1993) conclude that significant variables in wine consumption were income, a married status, and higher education studies. In terms of wine consumption demographic patterns in the US, authors like Martín de Mulas (2009) and Thach (2014) coincide that at the beginning of this century is when, in addition to a married status, feminine gender and a lower age, closer to 21 (the new generations) identify and describe the American consumer. Other authors such as Hussain et al (2006) agree that the wine consumption growth in the US has been significant because of the major consumption of the younger population. Gallego (2014) points out that large consumers continue to have the highest family income. Camillo (2012) indicates that level of studies is an important factor influencing the buying and consumption behavior of Chinese wine consumers.

Finally, the Contribution Variables have been introduced because, as Lockshin et al (2006) points out, "the incorporation of geographic factors together with the brand and price allow us to measure the sensitivity of the wine consumer". The incorporation of these dichotomous variables allows the modeling of characteristics of the transverse units that do not change over time but which do affect the result of our interest (Aparicio and Márquez, 2005).

The descriptive statistics of the variables are included in Table II. As it can be seen, there is a wide range of variation of results, fundamentally for two reasons. 
Table I

Variables of the Empirical Model

Variáveis do modelo empírico

\begin{tabular}{|c|c|c|c|}
\hline Variables & Abbreviation & Typology & Description and Source \\
\hline $\begin{array}{l}\text { Dependent Variable } \\
\text { Wine Consumption }\end{array}$ & $\mathrm{Y}$ & Continuous & $\begin{array}{l}\text { Wine Consumption (liters per capita) } \\
\text { Source: Anderson and Nelgen (2011) and Euromonitor } \\
\text { (2015) }\end{array}$ \\
\hline $\begin{array}{l}\text { Environment Variable } \\
\text { Wine Price }\end{array}$ & WPX & Continuous & $\begin{array}{l}\text { Wine Unit Price per Liter }(€ / l) \\
\text { Source: Euromonitor (2015) }\end{array}$ \\
\hline Production & PROD & Continuous & $\begin{array}{l}\text { Wine Production (liters) } \\
\text { Source: Anderson and Nelgen (2011) and Euromonitor } \\
\text { (2015) }\end{array}$ \\
\hline CAP1999 & CAP99 & Discrete & $\begin{array}{l}\text { Common Agricultural Policy (CAP) of 1999, 0: } 1990 \text { to } \\
\text { 1999; 1: } 2000 \text { to 2008, 0: 2009-2014 }\end{array}$ \\
\hline CAP2008 & CAP08 & Discrete & $\begin{array}{l}\text { Common Agricultural Policy (CAP) of 2008; 0: } 1990 \text { to } \\
\text { 2008; 1: } 2009 \text { to } 2014\end{array}$ \\
\hline $\begin{array}{l}\text { Consumer Variables } \\
\text { Income }\end{array}$ & INCO & Continuous & $\begin{array}{l}\text { Average Real Household Income (€) } \\
\text { Source: Euromonitor (2015) }\end{array}$ \\
\hline Age & AGE & Discrete & $\begin{array}{l}\text { 1: If the highest rate of variation of the population is } \\
\text { between } 21-30 \text { years } \\
2 \text { : If the highest rate of variation of the population is } \\
\text { between } 31-40 \text { years } \\
3: \text { If the highest rate of variation of the population is } \\
\text { between } 41-50 \text { years } \\
4 \text { : If the highest rate of variation of the population is } \\
\text { between } 51-60 \text { years } \\
5 \text { : If the highest rate of variation of the population is } 60 \\
\text { and + years } \\
\text { Source: Euromonitor (2015) }\end{array}$ \\
\hline Gender & GEN & Discrete & $\begin{array}{l}\text { 1: If the highest rate of variation of the population is } \\
\text { masculine } \\
\text { 2: If the highest rate of variation of the population is } \\
\text { feminine } \\
\text { Source: Euromonitor (2015) }\end{array}$ \\
\hline Education & EDUC & Discrete & $\begin{array}{l}\text { 1: If the highest rate of variation of the population is high } \\
\text { school's educated } \\
\text { 2: If the highest rate of variation of the population is } \\
\text { bachelor's educated } \\
\text { Source: Euromonitor (2015) }\end{array}$ \\
\hline $\begin{array}{l}\text { Marital Status - } \\
\text { Married }\end{array}$ & CSMAR & Continuous & $\begin{array}{l}\text { Married Couples } \\
\text { Source: Euromonitor (2015) }\end{array}$ \\
\hline Beer Consumption & BEER & Continuous & $\begin{array}{l}\text { Beer Consumption (liters per capita) } \\
\text { Source: Euromonitor (2015) }\end{array}$ \\
\hline \multicolumn{4}{|l|}{ Contribution Variables } \\
\hline France & FR & Discrete & 1: France; 0: rest of countries \\
\hline Italy & IT & Discrete & 1 : Italy; 0 : rest of countries \\
\hline Spain & SP & Discrete & 1: Spain; 0: rest of countries \\
\hline United Kingdom & UK & Discrete & 1: United Kingdom; 0: rest of countries \\
\hline Germany & $\mathrm{DE}$ & Discrete & 1: Germany; 0: rest of countries \\
\hline
\end{tabular}


Table II

Descriptive statistics of the variables

Estatística descritiva das variáveis

\begin{tabular}{|c|c|c|c|c|c|c|}
\hline $\begin{array}{l}\text { Dependent } \\
\text { Variables }\end{array}$ & $\mathrm{N}$ & Minimum & Maximum & Media & & $\begin{array}{c}\text { Typical } \\
\text { Deviation }\end{array}$ \\
\hline $\mathbf{Y}$ & 125 & 11.2 & 74.5 & 33.99592 & & 15.02287 \\
\hline $\begin{array}{c}\text { Independent } \\
\text { Variables } \\
\text { (Continuous) }\end{array}$ & $\mathrm{N}$ & Minimum & Maximum & Media & & $\begin{array}{c}\text { Typical } \\
\text { Deviation }\end{array}$ \\
\hline WPX & 125 & 1.330864 & 10.6 & 4.787681 & & 3.376747 \\
\hline PROD & 125 & 1000000 & $6.58 \mathrm{e}+09$ & $2.98 \mathrm{e}+09$ & & $2.22 \mathrm{e}+09$ \\
\hline INCO & 125 & 8442.8 & 36099.4 & 24692.83 & & 6848.612 \\
\hline MSMAR & 125 & -165100 & 267800 & 1811.689 & & 73485.15 \\
\hline BEER & 125 & 25.3 & 145.5 & 71.78176 & & 37.66911 \\
\hline $\begin{array}{c}\text { Independent } \\
\text { Variables } \\
\text { (Discrete) }\end{array}$ & Freq $(=0)$ & Freq. $(=1)$ & Freq. $(=2)$ & Freq. $(=3)$ & Freq. $(=4)$ & Freq. $(=5)$ \\
\hline CAP99 & 80 & 45 & & & & \\
\hline CAP08 & 95 & 30 & & & & \\
\hline AGE & & 0 & 18 & 30 & 50 & 22 \\
\hline GEN & & 13 & 107 & & & \\
\hline EDUC & & 75 & 45 & & & \\
\hline FR & 100 & 25 & & & & \\
\hline IT & 100 & 25 & & & & \\
\hline SP & 100 & 25 & & & & \\
\hline UK & 100 & 25 & & & & \\
\hline DE & 100 & 25 & & & & \\
\hline
\end{tabular}

The first reason is that the large producing countries are mixed with others that are not significant producers. France, Italy and Spain, which account for $47.8 \%$ of world production and $81 \%$ of the European Union, are mixed with the United Kingdom and Germany accounting for only 3.3\% of world production and $6 \%$ of the European Union (OIV, 2015). In 2014, the first wine producing country was France with 46.7 million hL, followed by Italy with 44.7 million hL, and Spain with 41.6 million hL. To a further distance was Germany with 9.2 million hL, and the United Kingdom with 1.4 million hL (OIV, 2015).

The second reason is that these two groups, France, Italy, and Spain in one side, and Germany and the United Kingdom in the other, show different behaviors in wine consumption. A consumption tendency function is calculated, $\gamma_{n}=\theta_{0}+\theta_{1} t_{t \mathrm{t}}$, where $Y$ is the consumption of wine in each country $i$ (data from Anderson and Nelgen 2011 and
Euromonitor 2015). France, Italy and Spain have a tendency, $\theta_{1}$, that decreases between 1990 and 2014: $\theta_{1}=-1.49, \theta_{1}=-0.73$ and $\theta_{1}=-057$, respectively. In contrast, the United Kingdom and Germany have a growing tendency, $\theta_{1}=0.56$ and $\theta_{1}=0.1671$, respectively.

In order to complete this information and given the disparity of data, an analysis was carried out to establish the possible differences in consumption in all five countries; The analysis gave two groups of countries: Group I, producing and exporting countries (France, Italy and Spain), and Group II, net importing countries (United Kingdom and Germany). The nonparametric Mann-Whitney contrast has to be applied; the reason of its use is the rejection of the Null Hypothesis of Normality in the Kolmogorov-Smirnov test (with a Kolmogorov-Smirnov $\mathrm{Z}$ value of 4,966 and a p-value of 0 ). The contrast of two independent samples with a U value of Mann-Whitney of 194 and 
a p-value of 0 indicates the existing difference in wine consumption between Group I and Group II.

Data analysis is completed by calculating the correlation between pairs of exogenous variables to avoid problems of linear dependence between them.
Table III shows how the values of the coefficients are not relatively high, so as to affirm that there is no evidence of multicollinearity.

Table III

Independent variable correlation coefficients

Coeficientes de correlação de variáveis independentes

\begin{tabular}{|c|c|c|c|c|c|c|c|c|c|c|c|c|c|c|c|}
\hline & BEER & WPX & PROD & AGE & GEN & CSMAR & INCO & EDUC & CAP99 & CAP08 & UK & FR & SP & IT & DE \\
\hline BEER & 1 & -0.1312 & -0.5235 & -0.0194 & -0.4480 & -0.5092 & -0.0299 & 0.1218 & 0.0137 & -0.1084 & 0.3006 & -0.4816 & 0.0270 & -0.2742 & 0.3328 \\
\hline WPX & & 1 & -0.1594 & 0.2472 & 0.2736 & 0.3568 & 0.5063 & 0.4129 & 0.0400 & 0.0499 & 0.6008 & 0.3081 & -0.4154 & -0.4090 & -0.3753 \\
\hline PROD & & & 1 & -0.1214 & 0.2845 & 0.4225 & -0.1107 & -0.3575 & -0.0183 & -0.0648 & -0.4658 & 0.5025 & 0.0984 & 0.5188 & -0.4642 \\
\hline AGE & & & & 1 & -0.1065 & -0.0149 & 0.4164 & 0.1725 & 0.0635 & 0.3654 & 0.1274 & 0.1274 & -0.1582 & -0.1143 & 0.0176 \\
\hline GEN & & & & & 1 & 0.4154 & -0.1963 & 0.2146 & 0.1592 & -0.2322 & 0.1743 & 0.1743 & 0.1072 & 0.1743 & -0.6301 \\
\hline CSMAR & & & & & & 1 & -0.1154 & 0.3082 & -0.0051 & 0.0128 & 0.2312 & 0.2440 & 0.0490 & 0.4445 & -0.3651 \\
\hline INCO & & & & & & & 1 & 0.1794 & 0.2986 & 0.3902 & 0.1193 & 0.4369 & -0.3449 & -0.1867 & 0.1773 \\
\hline EDUC & & & & & & & & 1 & 0.1822 & 0.1093 & 0.4455 & 0.0000 & 0.1291 & -0.3873 & -0.3873 \\
\hline CAP99 & & & & & & & & & 1 & -0.4264 & 0.0123 & -0.0030 & -0.0030 & -0.0030 & -0.0030 \\
\hline CAP08 & & & & & & & & & & 1 & 0.0092 & -0.0023 & -0.0023 & -0.0023 & -0.0023 \\
\hline UK & & & & & & & & & & & 1 & -0.2462 & -0.2462 & -0.2462 & -0.2462 \\
\hline FR & & & & & & & & & & & & 1 & -0.2525 & -0.2525 & -0.2525 \\
\hline SP & & & & & & & & & & & & & 1 & -0.2525 & -0.2525 \\
\hline IT & & & & & & & & & & & & & & 1 & -0.2525 \\
\hline DE & & & & & & & & & & & & & & & 1 \\
\hline
\end{tabular}

Taking into account this result, three models are estimated: a) a general model that integrates the five countries, and then b) a sub-model for the countries of Group I, and c) another sub-model for the countries of Group II.

Pooled Cross Section Time Series were used for the study to ensure a valid statistical inference. In particular, the Driscoll and Kraay correction was handled for the general model and for the Group I sub-model, while the Pooled OLS was used for the Group II sub-model.

To explain the variables that influence wine consumption in Europe, a model has been proposed, but not including the independent term, $X_{0}$, in order to avoid multicollinearity from the dummy variables

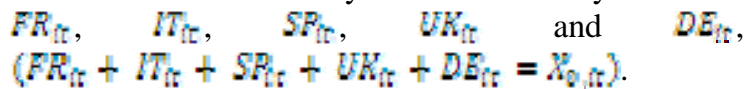

Substituting $X_{k i t}$ by the set of exogenous variables is obtained:

$$
\begin{aligned}
& \gamma_{t}=\sum_{n=1}^{n} \beta_{n} X_{h t}+u_{n}=\beta_{1} W P X_{t t}+\beta_{2} P R O D_{n}+\beta_{3} C A P 9 g_{t}
\end{aligned}
$$

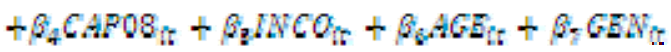

$$
\begin{aligned}
& +\beta_{\mathrm{g}} E D U C_{\pi}+\beta_{\mathrm{s}} \operatorname{HSWAR}_{\pi}+\beta_{10} B E E R_{\pi}+\beta_{11} F R_{\pi} \\
& +\beta_{12} / T_{n}+\beta_{1:} S F_{n}+\beta_{14} U K_{n t}+\beta_{12} D E_{n t}+w_{n}
\end{aligned}
$$

With $i=1,2, \ldots, 5$; $t=1990,1991, \ldots, 2014$.

To explain the differences in consumption between Group I and Group II, two sub-models were estimated from model (1). The variables $F R_{i t}, I T_{\mathrm{ft}}, S P_{\mathrm{ft}}, U K_{\mathrm{t}}$ and $D E_{\text {it }}$ were deleted and the independent term, $X_{0: \text { : }}$ was added. The equation to be estimated is: 


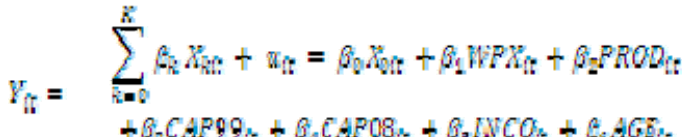

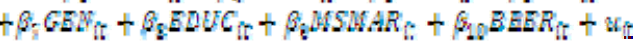

With $i=1,2,3$ (FR, IT, SP) for Group $I$ and $i=4$, 5(UK, DE) for Group II; $t=1990,1991, \ldots, 2014$.

The variable $Y_{i t}$ assumes the per capita consumption values. The independent variables handled are diverse and are classified into two categories. The first category is the Variables of the Environment: wine price (WPX), impact of European policies - Common Agricultural Policies (CAP99, CAP08), and country's wine production (PROD). The second set of variables are the Variables of the Consumer: income (INCO), age (AGE), gender (GEN), level of education (EDUC), marital status - married (MSMAR), and beer consumption (BEER). In the general model, a third category is included: Contribution Variables: five dummies, one for each country, France (FR), Italy (IT), Spain (SP), United Kingdom (UK) and Germany (DE), in order to understand the contributions and differences of the five countries in terms of wine consumption.

\section{RESULTS AND DISCUSSION}

The Wald, Wooldridge and Breusch-Pagan tests identified, for the general model and the sub-model Group I, respectively, heteroskedasticity, autocorrelation and contemporary correlation. In contrast, the sub-model Group II made up of the countries of Germany and the United Kingdom showed errors either independent of each other or distributed identically with constant variance $\sigma_{u}^{2}$ (Table IV).

Table IV

Results of Wald Test, Wooldridge Test and Breusch-Pagan Test

Resultados do Teste de Wald, do Teste de Wooldridge e do Teste de Breusch-Pagan

\begin{tabular}{|c|c|c|c|}
\hline & Wald Test & Wooldridge Test & Breusch and Pagan Test \\
\hline General model & $\begin{array}{l}\operatorname{chi} 2(5)=58.54 \text { Prob }>\text { chi } 2= \\
0.0000\end{array}$ & $\begin{array}{l}F(1,4)=82.073 \text { Prob }>F= \\
0.0008\end{array}$ & $\begin{array}{l}\operatorname{chi} 2(10)=25.019 \\
\operatorname{Pr}=0.0053\end{array}$ \\
\hline Group I sub-model & $\begin{array}{l}\operatorname{chi} 2(3)=6.78 \text { Prob }>\text { chi } 2= \\
0.0188\end{array}$ & $\begin{array}{l}F(1,2)=65.735 \\
\text { Prob }>F=0.0149\end{array}$ & $\begin{array}{l}\operatorname{chi} 2(3)=13.134 \\
\operatorname{Pr}=0.0044\end{array}$ \\
\hline Group II sub-model & $\begin{array}{l}\operatorname{chi} 2(2)=0.63 \\
\text { Prob }>\text { chi2 }=0.7307\end{array}$ & $\begin{array}{l}F(1,1)=9.419 \\
\text { Prob }>F=0.2005\end{array}$ & $\begin{array}{l}\operatorname{chi} 2(1)=0.099 \\
\operatorname{Pr}=0.7532\end{array}$ \\
\hline
\end{tabular}

p-valor $\leq 0.05 \mathrm{H} 0$ is rejected: constant variance, nule autocovariances, transversal independence

Regarding the probable problems of heteroscedasticity, autocorrelation and contemporary correlation, three methods were tested, a) Feasible Generalized Least Squares estimators, b) Standard Errors Corrected for Panel or Prais-Winsten regression, and c) the correction of Driscoll and Kraay (Hoechle, 2007). Estimated the models by the three methods, the least sum of residual squares corresponded to the correction of Driscoll and Kraay (Table V).

For the Group II sub-model, on the one hand, the Ftest of significance of the fixed effects indicates that it is preferable to use the grouped model to the fixedeffects method $(F(1,37)=2.55$, Prob $>F=0.1190)$. On the other hand, testing the Breusch and Pagan tests for random effects indicates that the clustered model is better than the random effects model (chibar2 $(01)=0.00$, Prob $>$ chibar2 $=1.0000)$. Therefore, the Pooled OLS was applied.

Table V

Sum of residual squares

Soma dos quadrados residuais

\begin{tabular}{llll}
\hline & $\begin{array}{l}\text { FGLS } \\
\text { regression }\end{array}$ & $\begin{array}{l}\text { Prais-Winsten } \\
\text { regression }\end{array}$ & $\begin{array}{l}\text { Regression with } \\
\text { Driscoll-Kraay }\end{array}$ \\
\hline $\begin{array}{l}\text { General } \\
\text { model }\end{array}$ & 3.51 & 3.1798 & 3.1548 \\
$\begin{array}{l}\text { Group I } \\
\text { sub- } \\
\text { model }\end{array}$ & 5.5316 & 4.8130 & 4.7985 \\
\hline
\end{tabular}


The results of these analyzes are summarized in Table VI.

The Environment Variables present the expected behavior. Thus, the price variable (WPX) has relevance in the explanation of consumption; although in the producing countries, the segmentation in consumer prices makes this variable less determinant.

Table VI

Wine Consumer Profiles in Europe

Perfis dos consumidores de vinho na Europa

\begin{tabular}{|c|c|c|c|}
\hline & General model & Group I sub-model & Group II sub-model \\
\hline WPX & $\begin{array}{l}-6.223391 * * * \\
(-9.65)\end{array}$ & 0.0364402 & $\begin{array}{l}-1.004847 * \\
(-184)\end{array}$ \\
\hline PROD & $\begin{array}{l}1.1809 \\
(0.98)\end{array}$ & $\begin{array}{l}3.7609 * * * \\
(3.34)\end{array}$ & $\begin{array}{l}5.4409 \\
(1.51)\end{array}$ \\
\hline CAP99 & $\begin{array}{l}-3.620398 * * \\
(-2.19)\end{array}$ & $\begin{array}{l}-8.446647 * * \\
(-2.39)\end{array}$ & $\begin{array}{l}0.7233149 \\
(0.83)\end{array}$ \\
\hline CAP08 & $\begin{array}{l}-9.526658 * * * \\
(-3.78)\end{array}$ & $\begin{array}{l}-17.61166^{* * * *} \\
(-4.17)\end{array}$ & $\begin{array}{l}-0.2896482 \\
(-0.24)\end{array}$ \\
\hline INCO & $\begin{array}{l}0.0005674 * * * \\
(4.91)\end{array}$ & $\begin{array}{l}0.0007207 * * \\
(2.64)\end{array}$ & $\begin{array}{l}0.0004293 * * * \\
(5.52)\end{array}$ \\
\hline AGE & $\begin{array}{l}-0.044696 \\
(-0.20)\end{array}$ & $\begin{array}{l}-0.0854295 \\
(-0.11)\end{array}$ & $\begin{array}{l}-0.4026052 * \\
(-1.75)\end{array}$ \\
\hline GEN & $\begin{array}{l}-0.7302839 \\
(-0.65)\end{array}$ & $\begin{array}{l}2.045287 \\
(1.21)\end{array}$ & $\begin{array}{l}-0.5856373 \\
(-0.93)\end{array}$ \\
\hline EDUC & $\begin{array}{l}-4.579146 * * * \\
(-3.37)\end{array}$ & $\begin{array}{l}-4.665667 * * \\
(-2.32)\end{array}$ & $\begin{array}{l}8.283221 * \\
(1.60)\end{array}$ \\
\hline MSMAR & $\begin{array}{l}4.4706 \\
(0.86)\end{array}$ & $\begin{array}{l}-8.5306 * \\
(-1.74)\end{array}$ & $\begin{array}{l}0.0000255^{* * * *} \\
(4.46)\end{array}$ \\
\hline BEER & $\begin{array}{l}-0.1497518^{*} \\
(-1.67)\end{array}$ & $\begin{array}{l}-0.1327282 * * \\
(-2.11)\end{array}$ & $\begin{array}{l}0.0074822 \\
(0.27)\end{array}$ \\
\hline FR & $\begin{array}{l}100.4701 * * * \\
(9.25)\end{array}$ & $\begin{array}{l}- \\
-\end{array}$ & $\begin{array}{l}- \\
-\end{array}$ \\
\hline IT & $\begin{array}{l}55.00179 * * * \\
(7.00)\end{array}$ & $\begin{array}{l}- \\
-\end{array}$ & $\begin{array}{l}- \\
-\end{array}$ \\
\hline SP & $\begin{array}{l}49.03495^{* * * *} \\
(7.07)\end{array}$ & $\begin{array}{l}- \\
-\end{array}$ & - \\
\hline UK & $\begin{array}{l}87.33526 * * * \\
(12.33)\end{array}$ & $\begin{array}{l}- \\
-\end{array}$ & $\begin{array}{l}- \\
-\end{array}$ \\
\hline DE & $\begin{array}{l}49.95386 * * * \\
(4.77)\end{array}$ & $\begin{array}{l}- \\
-\end{array}$ & - \\
\hline Cons & - & $\begin{array}{l}23.69432 * * \\
(2.57)\end{array}$ & $\begin{array}{l}2.460917 \\
(0.25)\end{array}$ \\
\hline $\mathbf{F}$ & 2141.71 & 77.20 & 67.59 \\
\hline Prob $>$ F & 0 & 0 & 0 \\
\hline R-squared & 0.9935 & 0.8779 & 0.9481 \\
\hline Root MSE & 3.1548 & 4.7985 & 1.1867 \\
\hline
\end{tabular}

${ }^{*} \mathrm{p}<0.10 ;{ }^{*} \mathrm{p}<0.05 ; * * * \mathrm{p}<0.001$. Between parentheses, estimated coefficients t-statistics.

Wine production (PROD) is not relevant in terms of impacting to the general profile of the European wine consumer, countries that combine wine production and imports. This relates to the consumption of wine in the net importing countries (sub-model Group II), where the variable is also not significant. However, in the producing countries (sub-model Group I), and as expected, the variable is significant; the countries that produce the most are the ones which consume the most.

With regard to the European regulation of the Common Agricultural Policy (CAP), which seeks to promote domestic consumption, they have not favored wine consumption, having an internal negative influence on producing countries and showing irrelevancy to net importers countries. The 
CAP from 2008 has had a more negative influence than that of 1999.

The behavior of the Consumer Variables is key in the interpretation and description of the European wine consumer's profile in the last twenty five years.

Income (INCO) is significant and positive, as expected, indicating that the higher the per capita income is the higher the level of wine consumption. This is clearly in line with the fact that wine consumption has a high income elasticity, very determinant for its product segmentation. This is evidently happening in the three defined profiles, the general European profile, the European producers' profile, and the European net importers' profile, where a higher per capita income implies more accessibility in consumption and more differentiated and segmented purchasing strategies.

Neither the differentiation by age (AGE), nor gender (GEN), has a decisive influence on the aggregate consumption of wine. This fact confirms that women are approaching the dynamics of consumption of men, and that young people approach the more mature generations (classic consumers). In Group II wine consumption enters the younger generations. This information may lead us to assume there could be soon an interesting break point, a potential structural change of wine consumption where "millennials" will be the public-objective of the sustainability of wine consumption in Europe, an extremely important fact for the viability of the sector.

Regarding the consumer's education level (EDUC), the lower the education level, the more wine consumption is expected in the general European wine consumer profile and the European producers' profile. It is in the European net importers' profile that higher consumption is associated with a higher degree, making wine a drink with a more qualitative and less quantitative profile for this group of consumers in the United Kingdom and Germany. The consumption of wine in these countries has a biased component to a more informed and qualified demand.

On the case of married marital status (MSMAR), the European net importers' profile also favors the consumption of wine with a greater number of married couples, which implies that family consumption and restaurant's consumption is more propitious. To the general European wine consumer profile and the European producers' profile, marital status does not represent any significant difference, all types of people consume wine.

Finally, it could be said the beer (BEER) traditionally should be considered as a substitute good for wine, since an increase in beer consumption may lead to a reduction in wine consumption. This is happening and defining the general European wine consumer profile and the European producers' profile, but it is not a fact in the definition of the European net importers' profile, where there is no substitution effect, clearly deriving in a division of differentiated products, uncompetitive among them. This ensures and consolidates the growth of wine consumption in large importing countries (Germany and the United Kingdom), regardless of the customary presence of beer consumption.

These are some interesting results that come from the empirical analysis of Table VI; the European producers' profile (France, Italy, and Spain) shows still some clear differences with the European net importers' profile (United Kingdom and Germany). The empirical description of consumers from Germany and the United Kingdom presents their wine consumer profile with higher income, married, and higher level of education than those consumers of the European producers' profile, and the general European profile.

These results for the European net importers' wine consumer profile (sub-model Group II, Germany and the United Kingdom) are similar to those described by Villanueva et al. (2015) for nowadays American wine consumers' profile. Anglo-Saxon Germanic European (Germany and the United Kingdom) wine consumers present a socio-economic and demographic profile closer to the profile of American (United States) wine consumers than to their counterparts in Europe, Latin European wine consumers (France, Italy, and Spain).

The behavior of the Contribution Variables of the general model allows us to verify that the countries have been decisive in the dynamics of wine consumption, albeit to a very different degree. Of note are France, as still the major producer and consumer of wine in Europe, and the United Kingdom, which maintains its status of largest importer and international target market. Then there is, at a distant place, Germany, and the other two classic producers, Italy and Spain, which lose quantitative weight among the privileged places of wine consumption.

\section{CONCLUSIONS}

Although wine consumption has quantitatively converged towards an unified and close value for most of the European countries (Smith and Mitry, 2012), the article presents that net importers wine consuming countries in Europe, in this case Germany 
and the United Kingdom, have wine consumers that are demographically different compared to the traditional European wine consumer's profile from the producing wine countries, in this case France, Italy, and Spain. There are still major differences in the wine consumer profiles of both types of countries.

Through an econometric analysis of different demographic, production, consumption, and environmental variables, the article shows that wine consumers in Germany and the United Kingdom have different profiles to those of France, Italy, and Spain. The empirical description of consumers from Germany and the United Kingdom, alike to those of

\section{REFERENCES}

Aizenman J., Brooks E., 2005. Globalization and taste convergence: The case of wine and beer. NBER WPNo. 11228.

Anderson K., 2010. The world in globalizing wine markets: lessons from Australia. Wine Eco. Res. Centre (University of Adelaide) WPNo.0910.

Anderson K., Nelgen S., 2011. The global wine statistical compendium, 1961-2009. University of Adelaide, University of Monash and Government of Australia, Adelaide.

Antoniolli E., Alturria L., Ceresa A., Solsona J., Winter P., Galiotti H., Fonzar A., 2011. Vinos de Mendoza: relación precio en góndola versus calidad en degustación a ciegas. Rev. FCA UNCuyo, 43, 111-125.

Aparicio J., Márquez J., 2005. Diagnóstico y especificación de modelos panel en stata 8.0. Div. Est. Pol. IDE, 1, 1-11.

Bardaji I., 1993. El vino en EEUU (Wine in the U.S.A.). Rev. Estud. Agro-Soc., 163, 219-257.

Barisan L., Boatto V., Rossetto L., Salmaso L., 2015. The knowledge of Italian wines on export markets. Brit. Food J., 117, 117-138.

Bentzen J., Eriksson T., Smith V., 2001. Alcohol consumption in European countries: Time series based test of convergence. Cah. Econ. Sociologie Rurales, 60-61, 60-74.

Bentzen J., Nannerup N., Smith V., 1998. Testing the $\beta$ convergence hypothesis on the alcohol consumption in the European OECD countries. Cah. Sci. l'IECV, 2, 1-10.

Bernabéu R., Díaz M., Olivas R., Olmeda M., 2012. Consumer preferences for wine applying best-worst scaling: A Spanish case study. Brit. Food J., 114, 1228-1250.

Boatto V., Defrancesco E., Trestini S., 2011. The price premium for wine quality signals: Does retailers' information provision matter? Brit. Food J., 113, 669-679.

Briz i Godino I., 2002. Producción y consumo. In: Análisis Funcional: su aplicación al estudio de sociedades. 43-51. BAR International Series 1073, Madrid.

Bruwer J., Li E., 2007. Wine-related lifestyle (WRL) market segmentation: Demographic and behavioral factors. J. Wine Res., 18, 49-66.

Bruwer J., Li E., Reid M., 2002. Segmentation of the Australian wine market using a wine-related lifestyle approach. J. Wine Res., 13, 217-242. the United States, presents their wine consumer profile with higher income, married, and higher level of education than those consumers of the European wine producers' profile, and the general wine European profile.

The designed model has been able to detect certain novelties not previously captured in the literature, which can give clues and signs in order to pursue further qualitative analysis of wine consumers and wine consumption dynamics and its sustainability in traditional consumer countries and new consumer countries.

Camillo A.A., 2012. A strategic investigation of the determinants of wine consumption in China. IJWBR, 24, 68-92.

Caracciolo F., Cembalo L.,Pomarici E., 2013. The hedonic price for an Italian grape variety. Ital. J. Food Sci., 25, 289-294.

Casini L., Corsi A.,Goodman S., 2009a. Consumer preferences of wine in Italy applying best-worst scaling. IJWBR, 21, 64-78.

Casini L., Rungie C. ,Corsi A. M., 2009b. How loyal are Italian consumers to wine attributes? J. Wine Res., 20, 125-142.

Castillo J.S., Compés R., García Álvarez-Coque J.M., 2014. La regulación vitivinícola. Evolución en la UE y España y situación en el panorama internacional. Serie Eco, 23, 272-310.

Castillo J.S., Rodríguez M., 2009. Determinantes de la evolución del mercado de vino en España. Distr. y Cons., 108, 70-89.

Dal Bianco A., Boatto V., Caracciolo F., 2013. Cultural convergences in world wine consumption. Rev. FCA UNCuyo, 42, 219-231.

De-Magistris T., Gracia A., Albisu L., 2014. Wine consumers' preferences in Spain: an analysis using the best-worst scaling approach. Span. J. Agric. Res., 12, 5-29.

Duarte Alonso A., 2012. Promotional efforts of muscadine wines and muscadine-related products: the case of southern United States wineries. Int. J. Consum. Stud., 36, 702-709.

Euromonitor, 2015. Euromonitor passport global market information database. Retrieved at http://www.euromonitor.com Accessed January 30, 2017.

Estrella Orrego M., Defrancesco E., Gennari A., 2012. The wine hedonic price models in the "Old and New World": state of the art. Rev. FCA UNCuyo, 44, 205-220.

Folwell R.J., Hardy Jr. A.R., Mccracken V.A., Price D.W., 1991. Impacts of state laws on the consumption of wine per capita. Int. J. Consum. Stud., 15, 107-115.

Gallego L., 2014. El mercado del vino en Estados Unidos. 90 p. ICEX, Madrid.

Gallet C., 2007. The demand for alcohol: a meta-analysis of elasticities. Austr. J. Agric. Res. Eco., 51, 121-135.

Gil J., Sánchez M., 1997. Consumer preferences for wine attributes: a conjoint approach. Brit. Food J., 99, 3-11.

Hoechle D., 2007. Robust standard errors for panel regressions with cross-sectional dependence". Stata J., 7, 281-312. 
Hussain M., Castaldi R., Cholette S., 2006. Determinants of wine consumption of U.S. consumers: an econometric analysis. 3rd IJWBR Conference, Montpellier.

Johnson T., Bruwer J., 2003. An empirical confirmation of winerelated lifestyle segments in the Australian wine market. Int. J Wine Mark., 15, 5-33.

Lockshin L., Jarvis W., d'Hauteville F., Perrouty J.P., 2006. Using simulations from discrete choice experiments to measure consumer sensitivity to brand, region, price, and awards in wine choice. Food Qual. Pref., 17, 166-178.

Martín de Mulas R., 2009. Estudio de mercado el mercado del vino en Estados Unidos. Comunidad de Madrid, Madrid.

Mitry D.J., Smith D.E., 2009. Convergence in global markets and consumer behavior. Int. J. Consum. Stud., 33, 316-321.

Mora M., Moscarola J., 2010. Representations of the emotions associated with a wine purchasing or consumption experience. Int. J. Consum. Stud., 34, 674-683.

Ndanga L.Z.B., Louw A., van Rooyen J., 2009. Increasing domestic consumption of South African wines: identifying the key market segments of the "Black Diamonds". AAWE, W.P., 41, Business.

OIV, 2015. Report of the world vitiviniculture situation. Retrieved at http://www.oiv.int/en/oiv-life/2015-oiv-report-on-the-worldvitivinicultural-situationnbsp. Accessed January 30, 2017.

Palma D., Ortúzar J.D., Rizzi L., Casaubon G., Agosin E., 2014. Measuring consumer preferences using hybrid discrete choice models. AAWE, W.P., 137, Economics.

Pappalardo G., Scienza A., Vindigni G., D'Amico M., 2013. Profitability of wine grape growing in the EU member states. $J$. Wine Res., 24, 59-76.

Phillips S., Wilson J., 2016. GAIN (Global Agricultural Information Network) Report: United Kingdom. USDA Foreign Agricultural Service, Washington DC.

Ritchie C., 2007. Beyond drinking: the role of wine in the life of the UK consumer. Int. J. Consum. Stud., 31, 534-540.

Salvador J.A., 2016. Mercado internacional del vino. Intentos de modelización y estrategias territoriales de comercialización en España. 496 p. PhD Thesis, Universidad de Valladolid.

Sam A.G., Thompson S.R., 2012. Country of origin advertising and US demand of imported wine: an empirical analysis. Appl. Eco. Lett., 19, 1871-1877.

Sirieix L., Delanchy M., Remaud H., Zepeda L., Gurviez P., 2013. Consumers' perceptions of individual and combined sustainable food labels: a UK pilot investigation”. Int. J. Consum. Stud., 37, 143-151.
Smith D.E., Mitry D.J., 2006. Consumer sensitivity to changes in tax policy on consumption of alcohol. Int. J. Consum. Stud., 30, 247-255.

Smith D.E., Mitry D.J., 2007. Cultural convergence: consumer behavioral changes in the European wine market. J. Wine Res.., 18, 107-112.

Smith D.E., Mitry D.J., 2012. Implications of changes in the consumption of wine across the European continent. J. Bus. Behav. Sci., 24, 3.

Smith D.E., Skalnik J.R., 1995. Changing patterns in the consumption of alcoholic beverages in Europe and the United States. European Advances in Consumer Research, 2, 343-355.

Smith D.E., Solgaard H.S., Beckmann S.C., 1999. Changes and trends in alcohol consumption patterns in Europe. Int. J. Consum. Stud., 23, 247-260.

Summerfield M., 2013. Wine drinking culture in France: a national myth or a modern passion? J. Wine Res., 24, 81-82.

Szolnoki G., Hoffmann D., 2014. Consumer segmentation based on usage of sales channels in the German wine market. IJWBR, 26, 27 44.

Tempesta T., Giancristofaro R.A., Corain L., Salmaso L., Tomasi D., Boatto V., 2010. The importance of landscape in wine quality perception: an integrated approach using choice-based conjoint analysis and combination-based permutation tests. Food Qual. Pref., 21, 827-836.

Thach L., 2014. Trends in the US Wine Industry for 2014 - Sunny Cellars with Some Cobwebs. Retrieved from http://lizthach.wordpress.com/2014/03/26/trends-in-the-us-wine-

industry-for-2014-sunny-cellars-with-some-cobwebs/. Accessed September, 2017.

Thomas A., Pickering G., 2003. Behavioural segmentation: a New Zealand wine market application. J. Wine Res., 14, 127-38.

Villanueva E., Castillo J.S., García-Cortijo M.C., 2015. Who is drinking wine in the United States? The demographic and socioeconomic profile of U.S. wine consumers (1972-2012). Int. Food Agribus. Man., 18, 39-60.

Wiedmann K., Behrens S., Klarmann C., Hennigs N., 2014 Customer value perception: Cross-generational preferences for wine. Brit. Food J., 116, 1128-1142.

Yvon B., 2007. An overview of the wine market. What is the potential for Argentinean wines? Moet et Chandon Estate Wines, Asia-Pacific Division, Intl Wine Forum. 